Soc. Geogr. Discuss., 6, 39-50, 2010

www.soc-geogr-discuss.net/6/39/2010/

\title{
Participative environmental management and social capital in Poland
}

A. Hunka ${ }^{1, *}$ and W. T. de Groot ${ }^{1,2}$

${ }^{1}$ Centre for Sustainable Management of Resources, Radboud University Nijmegen, The Netherlands

${ }^{2}$ Institute of Environmental Science, Leiden University, The Netherlands "now at: Roskilde University, Department of Environmental, Social and Spatial Change, Denmark

Received: 23 April 2010 - Accepted: 28 April 2010 - Published: 18 May 2010

Correspondence to: A. Hunka (a.hunka@ science.ru.nl)

Published by Copernicus Publications.

Participative

environmental

management and

social capital

Title Page

Abstract

Introduction

Conclusions

References

Tables

Figures

14

$\Delta$

4

Back

Close

Full Screen / Esc

Printer-friendly Version

Interactive Discussion 


\section{Abstract}

Eastern European countries, such as Poland, are often used as exemplary in social capital studies. Upon entering the European Union, the low social capital level in Poland posed problems with implementing new regulations, particularly in the envi5 ronmental policy field. Environmental issues often present a high degree of complexity - and European legislation requires multi-stakeholder involvement in decision-making processes. Thus, the dilemma: on the one hand, there is a demand to engage and consult many actors; on the other hand, low social capital contributes to an administrative culture with a ubiquitous top-down approach taken by institutional decision-makers.

The paper addresses this problem from the perspective of social capital theory. A study of administrative culture and decision-making processes shows the way decisions are currently made. We also propose a way to achieve more participative environmental management.

\section{Introduction}

15 The number of European Union Member States has nearly doubled in recent years: ten countries accessed in 2004, followed by another two in 2007 . The majority of these were former communist-ruled "Peoples' Republics", and the EU expansion eventually ended the division of Europe decided in 1945 at the Yalta Conference. All of the new Member States took time to prepare for the accession beforehand, e.g. by implementing EU-compliant laws and regulations. Still, it seems that changes in the so-called "countries in transition" have been unexpectedly slow. Literature on the subject, for instance Paldam and Svendsen (2002) mentions that, since the amount of human and physical capital available are sufficient for much faster economic growth, the lack of social capital must explain the slow rate of changes. Without contending that this is necessarily true, it may serve as an inspiration to have a deeper look at social capital in Poland. We will do so, discussing the concept of social capital in the following sec-
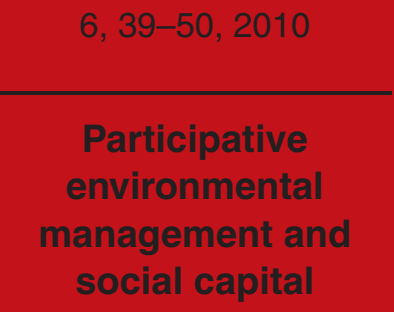

Title Page 
tion. The existing Polish situation and the way it affects decision-making processes will be discussed further. We conclude with solutions tailored for Polish conditions aiming at increase of bottom-up initiatives.

\section{Social capital - the Polish case}

5 Social capital is usually defined as the level of trust amongst people and the density of informal networks (Coleman, 1988; Putnam et al., 1993). This definition is often regarded as too vague (Arrow, 2000) and indeed it is if we do not distinguish between private and collective social capital (de Groot and Tadepally, 2008). Private social capital, a concept grounded in the work of Bourdieu (1986), is "owned" by individual actors 10 and may be equated to benefits that individual receives by virtue of being a member of a network of (trusted) others (Portes, 1998). Collective social capital, according to Putnam (2000) and Putnam et al. (1993), is a system-level characteristic of a group, and is commonly defined as a level of trust in the group as a whole and the strength of social bonds (networks) within the group.

15 Social capital may be put to uses deemed negative for society. Private social capital, for instance, may be geared towards corruption and nepotism, and collective social capital may be put to use to begin a war. This has given rise to the unfortunate term of "negative social capital" (Paldam and Svendsen, 2002; Wacquant, 1998), as if the capital itself would in the above cases be somehow negative (i.e. a debt). But most 20 often, social capital is seen as something benign. In the communitarian outlook, collective social capital is the quintessence of a society. We agree with the mainstream authors (Woolcock, 1998; World Bank, 1998) that collective social capital is a key to development. Socio-economic development relies, inter alia, on collective actions, and if people lack a pre-existing trust and networks, any initiative to undertake a collective 25 action requires enormous efforts in terms of time and energy ("transaction cost"), often to a degree that any collective action becomes effectively impossible.

Participative environmental management and social capital

Title Page

Abstract Introduction

Conclusions References

Tables Figures

14 $>1$

4

Back Close

Full Screen / Esc

Printer-friendly Version

Interactive Discussion 
Social capital can be measured in several ways. The closest to the mainstream definition of "trust and networks" is a combination of questioning people on the degree to which they trust each other, and on their involvement in (or density of) voluntary organisations (the latter is the so-called "Putnam's Instrument").

5 Studies on the subject highlight the low level of collective social capital in totalitarian regimes and centrally planned economies. The dictatorship theory of missing social capital (Paldam and Svendsen, 2002) points at two phenomena. The first is that authoritarian regimes actively destroy social capital such as voluntary associations in order to pre-empt any popular uprising. As suggested by Putnam et al. (1993), there 10 is a correlation between a level of social trust and the length of a period of a dictatorship, viz. the differences existing in present-day Italy between the southern part which for seven centuries formed the authoritarian Kingdom of Sicily, and the northern part with its long tradition of independent city states. The second element of the theory relates specifically to communist, centrally planned economies. In these regimes, total rationality is taken as to reside in the state, controlled by the Party that represents the people. Such an image of the state not only makes any feedback from the population unnecessary but also justifies a fine-grained, secret control of citizens, which turns trust into a very scarce good. This, combined with economic scarcities that used to prevail in communist economies, led people to focus on building solely private social 20 capital that could help to work around the state structures, e.g. through corruption and favouritism (Rose, 2000).

What happens if such societies enter into a transitional period, as did the Eastern European countries in 1989? Does the way of "getting things done" change? Is negative social capital replaced with trust and a co-operative spirit? Paldam and Svendsen 25 (2002) argue that this is not the case: Old mechanisms are self-perpetuating, as the case of Italy shows. Distrust between citizens and institutions has become generalized. Private dealings of corruption and political patronage, with their long history of proven efficacy, remain as the most adaptive behaviours, and block the way towards collective actions (and thereby retain their efficacy). Contemporary Poland appears to

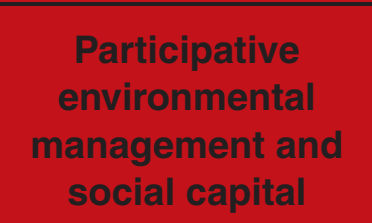

Title Page

Abstract

Conclusions

Tables

14

4

Back

Full Screen / Esc

Printer-friendly Version

Interactive Discussion 
be a case in point of this pessimistic vision. A study by Chloupkova et al. (2003) shows great differences in the level of collective social capital between Poland and Denmark, measured by (1) a density of voluntary associations; (2) an assessment of trust in other people, (3) an assessment of trust in formal institutions (legal system, police, adminis5 tration and government), and (4) civic participation (e.g. in elections). The results show that in Denmark, a citizen on average is a member of twelve times more voluntary organisations, trusts other countrymen three and a half times more, trusts institutions ten times more, and participates in twice as many civic actions as in Poland. According to historical data, the level of collective social capital (measured as membership in vol10 untary associations) was roughly similar in these two countries before the communist regime.

\section{Public participation in Poland}

Relations between the government and the public are a part of a country's collective social capital and have a strong influence on the efficacy of policy making and policy 15 implementation. If people distrust the government, they will tend to refuse to participate in policy making (if any invitation would be forthcoming), and rather resort to passive resistance, radical activism or working behind the scenes. In addition, if the authorities do not trust the intentions or knowledge of the public, why would they even invite people to participate? Here we can see the so-called vicious circle at work (Woolcock and 20 Narayan, 2000). In this section, we will study whether this situation is visible in presentday Poland.

Public participation in any environmental decision-making process is nowadays a widely recognised standard. The tenth principle of the Rio Declaration grants participation in environmental issues "of all concerned citizens at the relevant level" (p. 2). With the ratification of the Århus Convention, one of the state-of-the-art documents regarding access to information and participation in environmental matters, participatory principles have become implemented in the European Community legislation, with
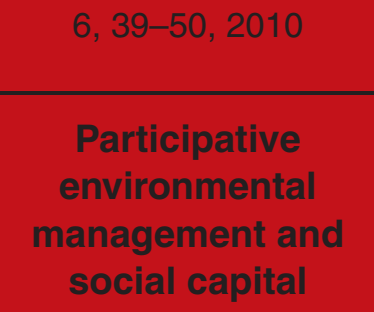

Title Page

Abstract Introduction

Conclusions References

Tables Figures

14

4

Back Close

Full Screen / Esc

Printer-friendly Version

Interactive Discussion 
the Water Framework Directive (2000/60/EC) as a notable example. Concerned citizens or stakeholders are defined as all interested and/or affected parties. Stakeholder involvement "at the relevant level", however, can be interpreted in many different ways.

Before joining the EU in 2004, Poland implemented the most up-to-date EC legisla5 tion into national regulations. Participation "at the relevant level" is therefore required by law. A study into the implementation of the EU Water Framework Directive (WFD) in Poland and Romania (Hunka and Palarie, 2008) showed that water management institutions do put participation into practice, but interpreted in the narrowest possible sense of exchanging information, and invitations to participate even in this sense 10 stop after one round of formal consultations. As one respondent of Hunka and Palarie (2008) said:

"There must be participation of the public, according to the law, and it must be also proved. I think, there are no investors who don't know (...) that they must reserve 3 or 4 weeks for public consultations. It would be suicidal, if they didn't do that." (p. 18)

15 The only role left for the public after the consultations is the role of a protester, and this then is how they become seen by the authorities a priori. Authorities complain, for instance, that:

[These] "calls from citizens, that the river stinks, that they observe dead fish floating, etcetera (...) The majority of these do not stem from a care for the environment, but 20 from a desire to sting neighbours, so, (...) next door squabbles are being transferred to the institutional levels." (Hunka and Palarie, 2008, p. 18)

"It is common that the local community leaders who should solve local problems do not work at all, so the cases are delegated to us. The competence is in locals but they want us to react, and if you go to the site (...) what you see is a bunch of huffy people on either side of a fence. It is a confusion of competences or rather indolence and negligence" (Hunka and Palarie, 2008, p. 18)

Whether these allegations are true or not, they indicate low collective social capital. If they are true, they imply that the people lack functioning conflict resolution structures. If they are untrue, they illustrate how authorities construct reasons to maintain their

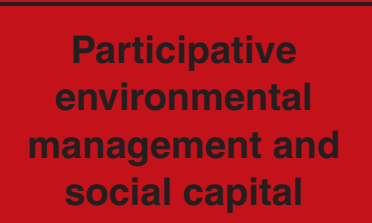

Title Page

Abstract Introduction

Conclusions References

Tables Figures

I

4

$>$

Back

Full Screen / Esc

Printer-friendly Version

Interactive Discussion 
attitude of distrust. The lack of participation cannot be attributed to the lack of interest in local environmental issues, since the Polish public is environmentally concerned (Hunka et al., 2009).

Legutko-Kobus (2007) in her study of Local Agenda 21 in 106 Polish districts dis5 cussed the most popular model of participation in Poland. The majority (96) of the districts implemented some sort of participation for their Local Agenda 21 development. In all cases participation was carried out by means of surveys and meetings with a wider public and local leaders. Interested parties were encouraged to give their feedback and opinions in all 96 cases. Still, the study shows that local authorities 10 expect one-way information flow, as no feedback is ever given back on the LA21 development process and its final results. A similar strategy was employed for a regional development strategy for the Lubelski Province. After an exemplary execution of the round-table meetings with the majority of the key and minor parties, authorities withdrew from further information exchange (Legutko-Kobus, 2007). The same author also 15 observed the development of obligatory plans (e.g. a local strategy for waste management) where participation is required as well. These kinds of documents are mostly produced by authorities after consulting co-workers and aldermen in order to fulfil the requirement of participative decision-making.

Another example widely discussed in Poland, is a case of the Augustów town by20 pass. In 1995, plans were made for creating the bypass, cutting in half the Rospuda River valley, a planned nature reserve and a NATURA 2000 site to be - a place of very high ecological value. The plans met with heated opposition from a number of NGOs and some environmentally concerned public, and even resulted in a negative reaction from the EU authorities (Adamowski, 1999; Szymczuk, 2007). After a number of peti25 tions to the European Commission, the EC started legal proceedings against Poland at the Court of Justice of the European Communities in March 2007. The legal actions triggered not only an attempt at conflict resolution, but also a rising participatory spirit, resulting in the beginning of 2008 in a series of roundtable meetings involving government officials from the Ministries of Environment and Infrastructure, NGO
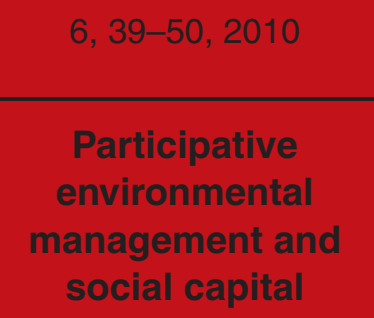

Title Page

Abstract Introduction

Conclusions References

Tables Figures

14

4

$\checkmark$

Back

Full Screen / Esc

Printer-friendly Version

Interactive Discussion 
representatives, concerned citizens, and independent experts. Together, they agreed on three alternative scenarios for the motorway and the bypass, and decided that construction works should await the decision of the European court. In May 2008, a new open tender for an environmental impact assessment of the investment was officially 5 announced. In July 2008, however, construction works at the Rospuda Valley were started (by the local government), following the plans of $1995 .^{1}$

The case of the Augustów bypass illustrates both the strength and the weakness of Paldam and Svendsen's (2002) theory of missing social capital. The fact that appeals were made directly to the EU shows a deep distrust of Poles in their own government, 10 and the fact that only the EU court could move the government to action showed that they were right. Moreover, the shocking final result shows that mechanisms described by the missing social capital theory are still at work. Yet, it must be concluded that the theory seems to break up at the same time, since after the government's response, the whole society enthusiastically joined in the participatory process, not only at the planning table but also in the streets, gathering to express their support or to protest, signing petitions and wearing a green ribbon of solidarity with the NGOs. People invested in their society and their government. In the end, they might feel cheated. Will they invest again?

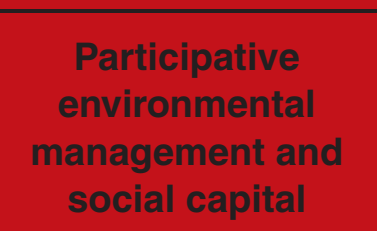

Title Page 


\section{Conclusions: Out of the vicious circle?}

Many authors have drafted lists of conditions for successful public participation (Arnstein, 1969; Webler et al., 2001). Factors that receive much attention in the literature are for instance: Legitimacy, which implies a focus on evidence and transparency; fair5 ness and equality; equal distribution of power, and a willingness to work towards a consensus, even amongst old adversaries. For Eastern Europe more specifically, conditions for success would appear to lie both on the side of the public authorities and on the side of the general public. Important factors for the public authorities are legitimacy, trust in lay citizens' decision-making abilities, and a willingness to shed and share their 10 power with the public. The same principles would appear to hold on the side of the public. Trust in authorities, a sense of ownership and responsibility combined with a willingness to become involved enable the process from the public side. Collective social capital is the common denominator of all these factors, essential for the efficacy with which they can be satisfied.

15 Woolcock and Narayan (2000) project the non-fulfilment of the above mentioned basic conditions as a vicious circle. A low level of trust and social capital generate a low level of participation, which then acts to further undermine trust.

de Groot and Tadepally (2008) in a sense echo this basic idea, but they end their study with a prescription of how to avoid the vicious circle. Their conclusion is that

20 if a development agency approaches communities with a proposal for some kind of a collective action (e.g. an irrigation system restoration, a community forest protection), only those communities should be selected that have enough collective social capital to be successful in the proposed action. Low capital communities would fail, which results in a further breakdown of social capital. Low capital communities can be supported by 25 actions geared towards the development of social capital first of all, and one way to do this is to invite the community into any collective action that they are able to carry out irrespective of the action's character (cleaning the school yard? revive the savings fund?). The success then breeds more social capital.
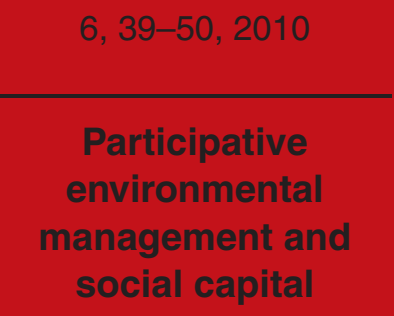

Title Page

Abstract

Conclusions

Tables

$1<$

4

Back

Full Screen / Esc

Printer-friendly Version

Interactive Discussion 
A tendency to adopt and implement not only legislation, but also Western European ready-made solutions for participation might be tempting, but it might be better to avoid copying the countries with a high level of collective social capital: in case an initiative fails, it might destroy the little trust accumulated, if people start searching for those 5 to blame. Still, small scale actions and grassroots initiatives within a community are the steps to rebuild social capital. NGOs, which are more trusted than government officials, can provide a necessary bridge between the authorities and the public, and employ local expertise and ecological knowledge (Olsson and Folke, 2001). "Green", non-governmental organisations have a long and established tradition in Poland, yet, 10 as the case of the Rospuda Valley illustrates, their role is too often limited to watchdog activities.

Employing independent experts can help in making the decision-making process more transparent. External evaluators and mediators, if they are able to communicate with the local stakeholders and at the same time avoid being perceived as taking 15 sides, can facilitate the process. Open access to environmental information, which is for many years now a common standard in Poland seems also promising, as it provides necessary transparency of environmental monitoring agencies. The need for independent experts is already acknowledged by institutional stakeholders (Hunka and Palarie, 2008).

20 For Poland, the advice would constitute targeted actions focused on cases and places where part/joint planning have a good enough basis in people's capacities and motivations. Such success could then be multiplied with good media coverage. In a way, the Augustów bypass is a case in point. Since every concerned party participated, in spite of the uncertain ending breaking down much of the effect, below the surface many positive networks of actors may have been built up.

Targeted actions can be reinforced by structural measures that would tilt the playing field of participation in the right general direction. Authority involvement in corruption combat and regulations supporting the growth of some local initiatives and associations can help to stimulate and rebuild trust between the public and the government. The
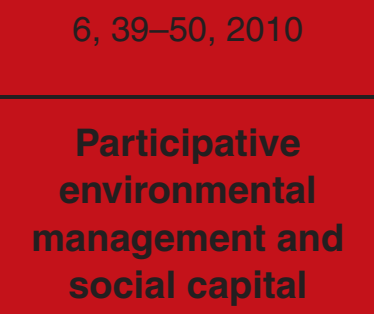

Title Page

Abstract

Conclusions

Tables

14

4

Back

Full Screen / Esc

Printer-friendly Version

Interactive Discussion 
EC regulations can normalize and facilitate communication amongst the bureaucrats, NGOs and public, even if by enforcement at first. Jointly, targeted actions and structural policies will, in our opinion, slowly but deeply change the participation scene in Poland and other Eastern European countries.

\section{References}

Adamowski, W.: Opinia w sprawie oddziaływania obwodnicy Augustowa na środowisko przyrodnicze projektowanego rezerwatu Rospuda, Dzikie Życie, 4, 1999. 45

Arnstein, S. R.: Ladder of Citizen Participation, J. Am. I. Planners, 35, 216-224, 1969. 47

Arrow, K. J.: Observations on social capital, The World Bank, Washington DC, USA, 2000. 41

10 Bourdieu, P.: The forms of capital, Greenwood, New York, USA, 1986. 41

Chloupkova, J., Svendsen, G. L. H., and Svendsen, G. T.: Building and destroying social capital: The case of cooperative movements in Denmark and Poland, Agr. Hum. Values, 20, 241252, 2003. 43

Coleman, J. S.: Social Capital in the Creation of Human-Capital, Am. J. Sociol., 94, S95-S120, 1988. 41

de Groot, W. T. and Tadepally, H.: Community action for environmental restoration: a case study on collective social capital in India, Environment, Development and Sustainability, 10, 519-536, 2008. 41, 47

Hunka, A. D. and Palarie, T. A.: WFD, Institutional Infrastructure, Decision-making and Stakeholders' Participation in Water Risk Management in Poland and Romania, in: EASY-ECO Vienna Conference: Governance by Evaluations: Institutional Capacities and Learning for Sustainable Development, Vienna, Austria, 2008. 44, 48

Hunka, A. D., de Groot, W. T., and Biela, A.: Visions of Nature in Eastern Europe: A Polish example, Environ. Value., 18, 429-452, 2009. 45

Legutko-Kobus, P.: Public participation in creation of documents on sustainable development exemplified by the Region of Lubelszczyzna, Prace naukowe AE im. Oskara Langego we Wrocławiu, Wrocław, Poland, 2007. 45

Participative

environmental

management and

social capital

Title Page

Abstract

Introduction

Conclusions

References

Tables Figures

14

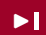

4

Back

Full Screen / Esc

Printer-friendly Version

Interactive Discussion 
Olsson, P. and Folke, C.: Local ecological knowledge and institutional dynamics for ecosystem management: A study of Lake Racken Watershed, Sweden, Ecosystems, 4, 85-104, 2001. 48

Paldam, M. and Svendsen, G. T.: Missing social capital and the transition in Eastern Europe, Journal for Institutional Innovation, Development and Transition, 5, 21-34, 2002. 40, 41, 42, 46

Portes, A.: Social Capital: Its origins and applications in modern sociology, Annu. Rev. Sociol., 24, 1-24, 1998. 41

Putnam, R. D.: Bowling alone: the collapse and revival of American community, Simon \& Schuster, New York, 2000. 41

Putnam, R. D., Leonardi, R., and Nanetti, R.: Making democracy work: civic traditions in modern Italy, Princeton University Press, Princeton, USA, 1993. 41, 42

Rose, R.: Getting things done in an anti-modern society: Social capital networks in Russia, The World Bank, Washington DC, USA, 2000. 42

15 Szymczuk, R.: Bruksela dla Rospudy, Dzikie Życie, wydanie Specjalne dla Rospudy, 2007. 45

Wacquant, L.: Negative social capital: State breakdown and social destitution in America's urban core, Journal of Housing and the Built Environment, 13, 25-40, 1998. 41

Webler, T., Tuler, S., and Krueger, R.: What is a good public participation process? Five perspectives from the public, Environ. Manage., 27, 435-450, 2001. 47

Woolcock, M.: Social capital and economic development: Toward a theoretical synthesis and policy framework, Theor. Soc., 27, 151-208, 1998. 41

Woolcock, M. and Narayan, D.: Social capital: Implications for development theory, research, and policy, World Bank Res. Obser., 15, 225-249, 2000. 43, 47

World Bank: Assessing aid: what works, what doesn't, and why, A World Bank policy research report, Oxford University Press, Washington DC, USA, 1998. 41

\section{SGD}

$6,39-50,2010$

\section{Participative}

environmental

management and

social capital

Title Page

Abstract

Introduction

Conclusions

References

Tables Figures

14

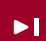

4

Back

Full Screen / Esc

Printer-friendly Version

Interactive Discussion 